Volume 10 Issue 2, April-June 2016: pp. 221-412. Copyright (c) 2015-2016 FIAT JUSTISIA. Faculty of Law, Lampung University, Bandarlampung, Lampung, Indonesia.

ISSN: 1978-5186 | e-ISSN: 2477-6238.

Open Access: http://jurnal.fh.unila.ac.id/index.php/fiat

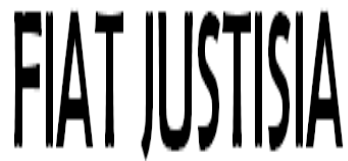

Fiat Justisia is licensed under a Creative Commons Attribution 4.0 International License, which permits unrestricted use, distribution, and reproduction in any medium, provided the original work is properly cited.

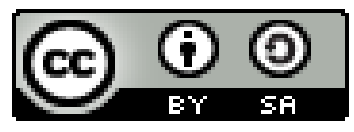

\title{
KEPASTIAN HUKUM DALAM PELELANGAN OBJEK HAK TANGGUNGAN SECARA ONLINE
}

\section{Legal Certainty in the Object of Liability Rights Auction Online}

\author{
Begiyama Fahmi Zaki \\ PT. BPR Eka Bumi Putra \\ email: begiyama@gmail.com
}

\begin{abstract}
an auction object the formal use of mortgage online in KPKNL arranged in Article 54 paragraph (3) Minister of Finance Regulation Number 106/PMK.06/2013 that the supply of indirect in writing can be done via email or the internet. The auction the object a mortgage via email done through the application of auction email (ALE), both in terms of registration prospective bidders and documents should be equipped with the determination of the winning bidder performed on these applications. Legal certainty in this case that is at the time of the registration process bidders up to set the winning bidder through ALE. This strengthens with the Law Number 11 of 2008 on information and electronic transaction, where Article 5 paragraph (1) described that information electronically and/or document electronic and/or result print is a legal evidence legitimate. The principle of legal certainty of the opinion that an auction had been conducted by KPKNL for the legal protection to parties concerned to an auction. This is in accordance with rights legislation are explained that when debtors injured promise, the holder the mortgage over its own power has the right to sell by auction common. Implementing auction made treatise auction by officials an auction is a certificate authentic in accordance with Article 1867 and 1868 the book the Act of Civil Law. Treatise auction used the seller/the owner goods, buyers and officials auction to maintain and carry out their rights and duties and have the power of perfect in accordance with Article 1 the 32 Minister of Finance Regulation Number 106/PMK.06/2013.
\end{abstract}

Key words: Legal Certainty, The Protection of the Law, Auction, Mortgage Object, Online 


\begin{abstract}
Abstrak
Penggunaan resmi obyek lelang hipotek secara online di KPKNL diatur dalam Pasal 54 ayat (3) Peraturan Menteri Keuangan Nomor 106/PMK.06/2013 yang pasokan tidak langsung secara tertulis dapat dilakukan melalui email atau internet. Lelang objek hipotek melalui email dilakukan melalui penerapan email lelang (ALE), baik dari segi pendaftaran calon peserta lelang dan dokumen harus dilengkapi untuk penentuan pemenang lelang dilakukan pada aplikasi ini. Kepastian hukum dalam hal ini yaitu pada saat bidder proses pendaftaran hingga mengatur pemenang tender melalui ALE. Ini telah memperkuat dengan Undang-Undang Nomor 11 Tahun 2008 tentang informasi dan transaksi elektronik, di mana Pasal 5 ayat (1) dijelaskan informasi yang elektronik dan/atau dokumen elektronik dan/atau hasil cetak adalah bukti hukum yang sah. Prinsip kepastian hukum berpendapat bahwa lelang telah dilakukan oleh KPKNL untuk perlindungan hukum kepada pihak yang berkepentingan untuk lelang. Hal ini sesuai dengan undang-undang hak dijelaskan bahwa ketika debitur cedera janji, pemegang hipotek atas kekuatan sendiri memiliki hak untuk menjual melalui lelang umum. Menerapkan lelang dibuat risalah lelang oleh pejabat lelang adalah sertifikat otentik sesuai dengan Pasal 1867 dan 1868 Kitab UndangUndang Hukum Perdata. Risalah lelang digunakan penjual/pemilik barang, pembeli dan pejabat lelang untuk mempertahankan dan melaksanakan hak dan kewajiban mereka dan memiliki kekuatan yang sempurna sesuai dengan Pasal 1 Menteri 32 Keuangan Nomor 106/PMK.06/2013.
\end{abstract}

Kata Kunci: Kepastian Hukum, Perlindungan Hukum, Lelang, Objek Hipotek, Online

\title{
A. Pendahuluan
}

Lelang adalah suatu penjualan barang di muka umum dengan cara penawaran secara lisan dan naik-naik untuk memperoleh harga yang semakin meningkat atau dengan penawaran harga yang semakin menurun dan/atau dengan penawaran harga secara tertutup dan tertulis yang didahului dengan usaha mengumpulkan para calon peminat/pembeli lelang yang dipimpin oleh pejabat lelang. ${ }^{1}$ Lelang yang dimaksud dalam hal ini ialah sebagai salah satu alternatif menjual barang. Hal ini sangatlah berbeda dengan lelang pengadaan barang atau jasa dalam rangka pelaksanaan Anggaran Pendapatan dan Belanja Negara (APBN) antara Pemerintah dengan Badan Hukum yang menawarkan barang atau jasa.

\footnotetext{
${ }^{1}$ Pasal 1 Vendu Reglement, sebagaimana tertulis dalam Sutarjo. (1995). "Pelelangan Dalam Rangka Eksekusi Oleh Pengadilan Negeri dan PUPN, Serta Aspek-Aspek Hukum yang Timbul Dalam Praktek", Makalah Penyuluhan Lelang, Medan, p. 22.
} 
Pelelangan objek Hak Tanggungan erat kaitannya dengan wanprestasi dari debitur terhadap kreditur. Wanprestasi yang dimaksud yaitu di dalam perjanjian kredit yang diikuti dengan Hak Tanggungan, debitur sudah tidak mampu lagi atau tidak adanya itikad baik untuk membayar kewajibannya kepada kreditur, sehingga barang jaminan yang di bebankan hak tanggungan dijual kepada pihak lain untuk melunasi kewajiban debitur terhadap kreditur (biasanya dengan proses lelang jaminan). Pada dasarnya ada banyak sebab terkait peralihan hak atas tanah beberapa diantaranya yaitu:

1. Peralihan hak atas tanah karena pewarisan tanpa wasiat; dan

2. Peralihan hak atas tanah karena pemindahan hak, salah satu bentuk pemindahan haknya bisa melalui proses jual beli, karena perbuatan hukum pemindahan hak atas tanah yang bersangkutan sengaja dialihkan kepada pihak lain. ${ }^{2}$ Pelelangan objek Hak Tanggungan merupakan salah satu cara perolehan hak atas tanah tersebut.

Peralihan hak atas tanah melalui lelang dilakukan dalam rangka pelunasan hutang yang dijamin dengan Hak Tanggungan. Pasal 1 UndangUndang Nomor 4 Tahun 1996 tentang Hak Tanggungan menjelaskan bahwa Hak Tanggungan adalah hak jaminan yang dibebankan pada hak atas tanah sebagaimana dimaksud dalam Undang-Undang Nomor 5 Tahun 1960 tentang Peraturan Dasar Pokok-Pokok Agraria, berikut atau tidak berikut benda-benda lain yang merupakan satu kesatuan dengan tanah itu, untuk pelunasan utang tertentu, yang memberikan kedudukan yang diutamakan kepada kreditor tertentu terhadap kreditor-kreditor lain.

Kreditor-kreditor tertentu yang dimaksud dalam hal ini yaitu kreditur yang memiliki peringkat pertama yang lebih dahulu diutamakan untuk melakukan penjualan jaminan dan pelunasan piutangnya. Barulah krediturkreditur lain sesuai peringkatnya, yang dapat meminta haknya. Pasal 5 Undang-Undang Hak Tanggungan menjelaskan bahwa apabila suatu objek hak tanggungan dibebani dengan lebih dari satu hak tanggungan, peringkat masing-masing hak tanggungan ditentukan tanggal pendaftarannya pada Kantor Pertanahan.

Pemberian hak tanggungan hanya dimungkinkan apabila dibuat dalam bentuk perjanjian. Pasal 1320 Kitab Undang-Undang Hukum Perdata (KUHPdt.) menjelaskan bahwa syarat sahnya perjanjian yakni:

1. Sepakat mereka yang mengikatkan dirinya;

2. Kecakapan untuk membuat suatu perjanjian;

3. Suatu hal tertentu; dan

4. Suatu sebab yang halal.

\footnotetext{
${ }^{2}$ Harsono, Boedi. (1999). Hukum Agraria Indonesia, Sejarah Pembentukan Undang-Undang Pokok Agraria, isi dan pelaksanaannya, Edisi Revisi. Jakarta: Djambatan, p. 317-318.
} 
Dengan demikian, eksekusi atau penjualan hak atas tanah yang dibebani dengan sertifikat Hak Tanggungan dapat dilaksanakan melalui 2 cara:

1. Lelang berdasarkan ketentuan Pasal 6 UUHT

Apabila debitor cidera janji, pemegang hak tanggungan pertama mempunyai hak untuk menjual obyek hak tanggungan atas kekuasaan sendiri melalui pelelangan umum serta mengambil pelunasan piutangnya dari hasil penjualan tersebut.

2. Lelang berdasarkan Pasal 20 ayat (1) huruf b jo. Pasal 14 ayat (2)

Rumusan Pasal 14 ayat (2) UUHT secara jelas menyatakan bahwa sertifikat Hak Tanggungan mempunyai kekuatan eksekutorial sebagaimana halnya suatu putusan pengadilan yang telah berkekuatan hukum tetap.

Ada beberapa cara dalam melakukan pengajuan penawaran secara lelang melalui Kantor Pelayanan Kekayaan Negara dan Lelang (KPKNL), yang mana telah diatur dalam Pasal 54 Peraturan Menteri Keuangan (PMK) Nomor 93/PMK.06/2010 sebagaimana telah diubah PMK Nomor 106/PMK.06/2013 tentang Petunjuk Pelaksanaan Lelang, bahwa penawaran lelang langsung dan/atau penawaran lelang tidak langsung dilakukan dengan cara:

1. Lisan, semakin meningkat atau semakin menurun;

2. Tertulis; atau

3. Tertulis dilanjutkan dengan lisan, dalam hal penawaran tertinggi belum mencapai Nilai Limit.

Terdapat dua jenis penawaran lelang yakni langsung dan tidak langsung. Untuk penawaran lelang langsung, peserta lelang yang sah atau kuasanya pada saat pelaksanaan lelang harus hadir di tempat pelaksanaan lelang. Dengan kata lain penawaran secara langsung adalah jenis penawaran yang konvensional atau umum, sebelum adanya aturan penawaran secara tidak langsung. Dengan demikian, asas kepastian hukum antara para pihak penjual, pembeli, pemilik obyek tanah sebelumnya, serta pihak lain yang berkepentingan didalamnya sangatlah terlihat secara langsung sampai penetapan pemenang lelang.

Kepastian hukum sebagai asas yang mementingkan kepatutan dan keadilan, sangatlah erat kaitannya dengan asas lain dalam penjualan lelang yakni: ${ }^{3}$

1. Terbuka / transparan. Pelaksanaan lelang didahului dengan pengumuman dan lelang dilaksanakan di depan umum.

\footnotetext{
${ }^{3}$ Departemen Keuangan Republik Indonesia. (1995). Lelang Barang-Barang Milik Badan Usaha Milik Negara/Daerah. Bandung: Badan Urusan Piutang dan Lelang Negara, Kantor Wilayah IV Kantor Lelang Negara, p. 1.
} 
2. Kompetitif. Penawaran lelang bersifat kompetitif, dimana para peserta lelang menawar dengan harga yang bersaing tanpa diberi prioritas pada para pihak manapun dalam pelaksanaan pembelian obyek lelang tersebut.

3. Harga optimal/wajar. Pembeli ditunjuk berdasarkan peserta lelang yang melakukan penawaran harga tertinggi dan telah mencapai harga atau melebihi harga limit, sehingga ditemukan suatu harga barang yang optimal atau wajar sesuai dengan harga secara umum.

Selanjutnya, dalam penawaran lelang tidak langsung, peserta lelang yang sah atau kuasanya pada saat pelaksanaan lelang tidak diharuskan hadir di tempat pelaksanaan lelang dan penawarannya dilakukan dengan menggunakan teknologi informasi dan komunikasi. Ukuran sah atau tidaknya peserta lelang untuk mengikuti proses lelang adalah telah terpenuhinya syarat-syarat proses lelang online sesuai PMK No. 106/PMK.06/2013 tentang Petunjuk Pelaksanaan Lelang. Pada Pasal 54 ayat (3) dijelaskan bahwa Penawaran lelang secara tertulis tanpa kehadiran Peserta Lelang dilakukan:

a. melalui surat elektronik (email) ;

b. melalui surat tromol pos; atau

c. melalui internet.

Hal tersebut dikuatkan dengan lahirnya Undang-Undang Nomor 11 Tahun 2008 tentang Informasi dan Transaksi Elektronik (ITE). Pasal 1 angka 4 UU ITE menjelaskan bahwa dokumen elektronik adalah setiap informasi elektronik yang dibuat, diteruskan, dikirimkan, diterima, atau disimpan dalam bentuk analog, digital, elektomagnetik, optikal atau sejenisnya, yang dapat dilihat, ditampilkan, dan/atau didengar melalui Komputer atau Sistem Elektronik, termasuk tetapi tidak terbatas pada tulisan, suara, gambar, peta, rancangan, foto atau sejenisnya, huruf, tanda, angka, kode akses, simbol atau perforasi yang memiliki makna atau arti atau dapat dipahami oleh orang yang mampu memahaminya. Berdasarkan ketentuan tersebut maka definisi dan mekanisme penawaran lelang telah mendapat perluasan khususnya dari sudut media yang digunakan untuk menyelenggarakan lelang. Lelang bukan lagi hanya penjualan barang yang terbuka untuk umum secara langsung, melainkan juga secara tidak langsung melalui media elektronik salah satunya yaitu internet, dan dokumen elektronik tersebut sah menurut hukum terhadap proses pelelangan online sesuai Pasal 54 ayat (3) PMK No. 106/PMK.06/2013 tersebut di atas, bahkan yang telah tercetak sekalipun.

Adanya sistem pelelangan secara online bukan berarti menjadi jaminan kepastian hukum maupun asas yang berkaitan di dalamnya seperti transparansi, kompetitif maupun harga optimal akan terpenuhi. Dengan kata lain pelelangan secara online dapat menjadi terobosan dari sistem pelelangan secara konvensional, atau sebaliknya, bisa menjadi peluang bagi pihak yang tidak bertanggung jawab untuk mengambil keuntungan di dalamnya, 
termasuk penyelenggara pelelangan secara online. Hal ini berkaitan erat dengan akibat hukum yang timbul dari pelaksanaan pelelangan hak tanggungan, sehingga perlu terlihat lebih jelas dimana letak perlindungan hukum bagi pihak-pihak yang terkait seperti penjual/kreditor, debitor, pembeli dan pejabat lelang dalam proses pelaksanaan lelang hak tanggungan secara online.

Bertolak dari latar belakang di atas, dapat dirumuskan pokok permasalahan yaitu: Bagaimanakah kepastian hukum pelelangan objek hak tanggungan secara online?, dan bagaimanakah perlindungan hukum bagi pihak yang terkait dengan pelelangan objek hak tanggungan secara online?

Pendekatan masalah yang digunakan dalam penelitian ini adalah pendekatan hukum secara normatif dan empiris. Pendekatan normatif dilakukan dengan mempelajari, melihat dan menelaah mengenai beberapa hal yang bersifat teoritis yang menyangkut asas-asas hukum, konsepsi, pandangan, doktrin-doktrin hukum, peraturan hukum dan sistem hukum yang berkenaan dengan permasalahan penelitian ini. Pendekatan empiris berupa penerapan (implementasi) pada peristiwa hukum guna mencapai tujuan yang telah ditentukan.

\section{B. Pembahasan}

\section{Kepastian Hukum Dalam Pelelangan Objek Hak Tanggungan Secara Online}

Pelelangan terhadap objek Hak Tanggungan merupakan hal yang sah karena sebagai hak jaminan yang dibebankan pada hak atas tanah sebagaimana dimaksud dalam UUPA, berikut atau tidak berikut benda-benda lain yang merupakan satu kesatuan dengan tanah itu, untuk pelunasan utang tertentu, yang memberikan kedudukan yang diutamakan kepada kreditur tertentu terhadap kreditur-kreditur lain. Pertimbangan tersebut karena dalam pelelangan diperlukan lembaga hak jaminan yang kuat dan mampu memberikan kepastian hukum bagi pihak-pihak yang berkepentingan, yang dapat mendorong peningkatan partisipasi masyarakat dalam pembangunan.

Pelaksanaan eksekusi objek hak tanggungan melalui pelelangan atas alasan cidera janji tidak digantungkan pada jatuh tempo perjanjian kredit . Pasal 6 Undang-Undang Nomor 4 Tahun 1996 tidak menjelaskan faktor cidera janji, hanya menegaskan cidera janji menjadi dasar bagi pemegang hak tanggungan untuk melaksanakan haknya menjual obyek hak tanggungan. Hal itu diulangi kembali dalam penjelasan pasal tersebut yang mengatakan apabila debitor cidera janji, pemegang hak tanggungan berhak menjual obyek hak tanggungan atas kekuasaan sendiri, jika dalam Akta Pemberian Hak Tanggungan dicantumkan klausul demikian. Sertifikat Hak Tanggungan sebagai tanda bukti adanya Hak Tanggungan memuat irah-irah dengan kata-kata "Demi Keadilan Berdasarkan Ketuhanan Yang Maha Esa". 
Sertifikat Hak Tanggungan mempunyai kekuatan eksekutorial yang sama dengan putusan pengadilan yang telah memperoleh kekuatan hukum tetap dan berlaku sebagai pengganti Groose Acte Hypotheek sepanjang mengenai ha katas tanah. ${ }^{4}$

Eksekusi objek hak tanggungan atas alasan cidera janji dapat dilaksanakan, meskipun perjanjian kredit belum jatuh tempo. Pasal 6 dan Pasal 20 Undang-Undang Nomor 4 Tahun 1996 memberi hak menjual objek hak tanggungan atas alasan cidera janji. Apabila debitor cidera janji, pemegang hak tanggungan (kreditor) berhak untuk menjual obyek hak tanggungan, baik berdasarkan Pasal 224 HIR maupun atas dasar kekuasaan sendiri. Makna menjual objek hak tanggungan atas alasan cidera janji sama artinya dengan melakukan eksekusi terhadap objek hak tanggungan. Selain ketentuan dalam Pasal 6 dan Pasal 20 Undang-Undang Nomor 4 Tahun 1996, sesuai Pasal 1267 KUHPerdata juga memberi hak opsi kepada kreditur untuk mengambil tindakan apabila debitur wanprestasi, tanpa mempersoalkan apakah perjanjian telah jatuh tempo atau tidak, dengan ketentuan meminta atau menuntut kepada pengadilan untuk memaksa debitur memenuhi perjanjian, jika hal itu masih bisa dilakukan oleh debitur, atau menuntut pembatalan perjanjian disertai dengan penggantian biaya kerugian dan bunga.

Peraturan Menteri Keuangan Nomor 106/PMK.06/2013 Tentang Petunjuk Pelaksanaan Lelang, pada Pasal 1 angka 1 menjelaskan bahwa lelang adalah penjualan barang yang terbuka untuk umum dengan penawaran harga secara tertulis dan/ atau lisan yang semakin meningkat atau menurun untuk mencapai harga tertinggi, yang didahului dengan Pengumuman Lelang. Pasal ini menjelaskan bahwa penawaran harga secara lisan oleh peserta lelang dihadapan penjual dan pejabat lelang KPKNL, berlaku jika lelang tersebut dilakukan secara konvensional. Untuk sistem penawaran harga secara tertulis, dapat dilaksanakan dengan dua cara yaitu secara konvensional dan online, penawar lelang secara konvensional dapat melaksanakannya dengan menawar melalui media yang disediakan secara tertulis dengan penawaran di atas nilai limit $^{5}$ dan di atas harga penawar lainnya (jika peserta lelang lebih dari satu orang). Untuk penawaran secara online dilakukan melalui Aplikasi Lelang Email (ALE).

Adanya penawaran lelang secara online dilatarbelakangi bahwa pembangunan nasional haruslah dilakukan dengan proses yang berkelanjutan yang harus senantiasa tanggap terhadap berbagai dinamika yang terjadi di

\footnotetext{
${ }^{4}$ Sutedi, Adrian. (2010). Hukum Hak Tanggungan. Jakarta: Sinar Grafika, p. 118.

5 Sebagaimana dijelaskan dalam Pasal 1 angka 1, Peraturan Menteri Keuangan Nomor 106/PMK.06/2013, Nilai Limit adalah harga minimal barang yang akan dilelang dan ditetapkan oleh Penjual/Pemilik barang.
} 
masyarakat. Globalisasi informasi telah menempatkan Indonesia sebagai bagian dari masyarakat informasi dunia sehingga mengharuskan dibentuknya pengaturan mengenai pengelolaan Informasi dan Transaksi Elektronik di tingkat nasional sehingga pembangunan Teknologi Informasi dapat dilakukan secara optimal, merata, dan menyebar ke seluruh lapisan masyarakat guna mencerdaskan kehidupan bangsa. Untuk itu pemerintah perlu mendukung pengembangan Teknologi Informasi melalui infrastruktur hukum dan pengaturannya sehingga pemanfaatan Teknologi Informasi dilakukan secara aman dan dapat berperan penting dalam pertumbuhan perekonomian nasional untuk mewujudkan kesejahteraan masyarakat.

Asumsi dasar modernisasi seperti yang dimaksud di atas bahwa: ${ }^{6}$

a. Bertolak dari dua kutub dikotomis yaitu antara masyarakat modern (masyarakat negara-negara maju) dan masyarakat tradisional (masyarakat negara-negara berkembang);

b. Peranan negara-negara maju sangat dominan dan dianggap positif, yaitu dengan menularkan nilai-nilai modern disamping memberikan bantuan modal dan teknologi. Tekanan kegagalan pembangunan bukan disebabkan oleh faktor-faktor eksternal melainkan internal; dan

c. Resep pembangunan yang ditawarkan bisa berlaku untuk siapa, kapan dan dimana saja.

Pasal 54 ayat (3) Peraturan Menteri Keuangan Nomor 106/PMK.06/2013 menjelaskan bahwa penawaran lelang secara tertulis tanpa kehadiran Peserta Lelang dilakukan:

a. Melalui surat elektronik (email);

b. Melalui surat tromol pos; atau

c. Melalui internet.

Penawaran lelang objek Hak Tanggungan melalui surat elektronik (email) hanya dapat diajukan satu kali. Dalam hal terdapat Peserta Lelang yang mengajukan penawaran melaui surat elektronik (email) lebih dari satu kali untuk setiap objek lelang dengan nilai penawaran sebelumnya, maka nilai penawaran yang lebih tinggi dianggap sah dan mengikat. Penawaran Lelang melalui surat elektronik (email) dibuka pada saat pelaksanaan lelang, oleh Pejabat Lelang bersama dengan Penjual dan 2 (dua) orang saksi, masing-masing 1 (satu) orang dari KPKNL/ Kantor Pejabat Lelang Kelas II dan 1 (satu) orang dari Penjual. Pada Pasal 60 ayat (2) Peraturan Menteri Keuangan Nomor 106/PMK.06/2013 dijelaskan bahwa penawaran yang telah disampaikan oleh Peserta Lelang kepada Pejabat Lelang tidak dapat diubah atau dibatalkan oleh Peserta Lelang. Dalam hal terdapat Peserta Lelang yang mengajukan penawaran tertinggi yang sama melalui surat

\footnotetext{
${ }^{6}$ Budiman, Arif. (1984). Sosiologi Pembangunan dan Keterbelakangan Sosiologi. Jakarta: Pustaka Pulsar.
} 
elektronik (email), Pejabat Lelang mengesahkan Peserta Lelang yang penawarannya diterima lebih dahulu sebagai Pembeli. Hal tersebut disahkan dari dikirimnya surat elektronik sebagai pemenang lelang ke email peserta tersebut.

Pengesahan penawaran oleh pejabat lelang tersebut, adalah sah, hal itu dikuatkan dengan Pasal 1 Undang-Undang Nomor 11 Tahun 2008 tentang Informasi dan Transaksi Elektronik, yang di dalamnya menjelaskan bahwa Informasi Elektronik yang dibuat, diteruskan, dikirimkan, diterima, atau disimpan dalam bentuk analog, digital, elektromagnetik, optikal, atau sejenisnya, yang dapat dilihat, ditampilkan, dan/atau didengar melalui Komputer atau Sistem Elektronik, termasuk tetapi tidak terbatas pada tulisan, suara, gambar, peta, rancangan, foto atau sejenisnya, huruf, tanda, angka, Kode Akses, simbol atau perforasi yang memiliki makna atau arti atau dapat dipahami oleh orang yang mampu memahaminya. Terlihat bahwa pelelangan objek Hak Tanggungan secara online yaitu salah satunya melalui email, merupakan bagian dari dokumen elektronik melalui sistem elektronik.

Pada dasarnya sistem elektronik adalah serangkaian perangkat dan prosedur elektronik yang berfungsi mempersiapkan, mengumpulkan, mengolah, menganalisis, menyimpan, menampilkan, mengumumkan, mengirimkan, dan/atau menyebarkan Informasi Elektronik. Mempersiapkan, mengumpulkan, mengolah, menganalisis, menyimpan, menampilkan, mengumumkan, mengirimkan, dan/atau menyebarkan Informasi Elektronik, sehingga penyelenggaraan sistem elektronik dapat dilakukan oleh penyelenggara negara, Orang, Badan Usaha, dan/atau masyarakat. Salah satunya yang dilakukan oleh KPKNL Bandar Lampung.

Apabila penawar tertinggi atau yang disebut sebagai pemenang lelang wanprestasi, karena tidak membayar sisa uang dari harga barang yang dilelang, maka KPKNL akan mengambil uang jaminan yang sebelumnya telah disetorkan, dan dimasukkan ke kas negara, serta berhak untuk memasukkan orang tersebut ke daftar hitam lelang. Pembeli yang sudah masuk daftar hitam tersebut tidak dapat lagi menjadi peserta lelang dalam waktu tertentu. Mengingat objek lelang tidak jadi terjual, penjual barang lelang/ kreditor pemegang Hak Tanggungan dapat melakukan lelang ulang. Lelang ulang merupakan pelaksanaan lelang yang dilakukan untuk mengulang lelang yang tidak ada peminat, lelang yang ditahan atau lelang yang Pembelinya wanprestasi.

Sebagaimana diatur dalam Pasal 38 PMK No. 106/PMK.06/2013, pelaksanaan Lelang Ulang, termasuk di dalamnya lelang melalui email, dapat dilakukan serta nilai limit dapat diubah oleh Penjual (pemegang Hak Tanggungan) dengan ketentuan:

a. Menunjukkan hasil penilaian yang masih berlaku, dalam hal Nilai Limit pada lelang sebelumnya didasarkan pada penilaian oleh penilai; atau 
b. Menunjukkan hasil penaksiran yang masih berlaku, dalam hal Nilai Limit pada lelang sebelumnya didasarkan pada penaksiran oleh penaksir/ tim penaksir.

Menurut Harun Al-Rashid pada hakekatnya jual beli merupakan salah satu cara pengalihan hak atas tanah kepada pihak pembeli tanah dari pihak penjual tanah. ${ }^{7}$ Melalui penjualan secara lelang, pembeli akan terjamin kepastian hukumnya terhadap obyek tanah yang dilelang, dengan bukti terbitnya risalah lelang yang merupakan akta otentik dari pembelian suatu barang melalui proses lelang. Sehingga hak atas tanah yang dilelang akan jatuh kepada pemenang lelang meskipun belum secara sempurna, karena harus didaftarkan ke kantor pertanahan setempat guna memperoleh legitimasi yang sempurna.Lelang yang merupakan salah satu cara pemindahan hak atas tanah hanya dapat didaftarkan jika dibuktikan dengan kutipan risalah lelang yang dibuat oleh pejabat lelang.

Menurut ketentuan Pasal 36 ayat (1) dan (2) PP No. 24 Tahun 1997 menjelaskan bahwa risalah lelang merupakan bukti adanya peralihan hak secara langsung terjadinya suatu perubahan data yuridis terhadap tanah yang dijual melalui lelang umum tersebut, sehingga pemeliharaan pendaftaran tanah dilakukan apabila terjadi perubahan pada data fisik dan data yuridis obyek pendaftaran tanah yang telah terdaftar dan secara otomatis pemegang hak yang bersangkutan wajib mendaftarkan perubahan kepada Kantor Pertanahan setempat dimana tanah tersebut berada. Sehingga dari pendaftaran hak atas tanah tersebut akan diterbitkan sertifikat sebagai surat tanda bukti hak, dan diterbitkan untuk kepentingan pemegang hak yang bersangkutan.

Hal tersebut sebagaimana diatur didalam Peraturan Kepala Badan Pertanahan Nasional Nomor 8 Tahun 2012 tentang Perubahan Atas Peraturan Menteri Agraria/Kepala Badan Pertanahan Nasional Nomor 3 Tahun 1997 tentang Ketentuan Pelaksanaan PP No. 24 Tahun 1997 tentang Pendaftaran Tanah bahwa Risalah Lelang yang dibuat oleh Pejabat Lelang dapat dijadikan dasar untuk balik nama/pendaftaran tanah tersebut.

Pengaturan risalah lelang terdapat dalam Pasal 35 Vendu Reglement atau disebut Peraturan Lelang. Risalah lelang adalah sama artinya dengan "berita acara' Lelang, yang merupakan landasan otentik penjualan lelang, tanpa risalah lelang. Tanpa lelang yang dilakukan dianggap tidak sah. Risalah lelang mencatat segala peristiwa yang terjadi pada penjualan lelang. Sedangkan dalam Pasal 1 angka 32 Peraturan Menteri Keuangan Republik Indonesia Nomor 106/PMK.06/2013 tentang Perubahan atas Peraturan Menteri Keuangan Nomor 93/PMK.06/2010 tentang Petunjuk Pelaksanaan Lelang, Risalah Lelang merupakan berita acara pelaksanaan lelang yang

\footnotetext{
${ }^{7}$ Al-Rashid, Harun. (1997). Sekilas Jual Beli Tanah. Jakarta: Ghalia Indonesia, p. 50.
} 
dibuat oleh Pejabat Lelang yang merupakan akta otentik dan mempunyai kekuatan pembuktian sempurna.

\section{Perlindungan Hukum Bagi Pihak Yang Terkait Dengan Pelelangan Objek Hak Tanggungan Secara Online \\ a. Perlindungan Hukum Terhadap Pelelangan Objek Hak Tanggungan Secara Online Bagi Penjual/Kreditor}

Berlakunya UUHT, ketentuan mengenai Credietverband dalam S. 1908-542 jo. S. 1937-191 dan ketentuan mengenai Hypotheek dalam Buku II KUHPdt. Sepanjang mengenai pembebanan Hak Tanggungan pada hak atas tanah beserta benda-benda yang berkaitan dengan tanah tidak berlaku lagi. Atas dasar kenyataan tersebut, ditetapkanlah undang-undang mengenai lembaga hak jaminan atas tanah yang dalam hal ini memberikan perlindungan hukum bagi penjual/pihak kreditor. Lembaga hak jaminan yang oleh UUPA diber nama hak tanggungan ini memiliki beberapa ciri-ciri yang kuat.

Pertama, memberikan kedudukan yang diutamakan atau mendahulu kepada pemegangnya. Pasal 6 UUHT menyatakan bahwa "apabila debitor cidera janji, pemegang Hak Tanggungan pertama mempunyai hak untuk menjual objek Hak Tanggungan atas kekuasaan sendiri melalui pelelangan umum serta mengambil pelunasan piutangnya dari hasil penjualan tersebut". Hal ini menjelaskan bahwa kreditor sebagai penjual objek hak tanggungan mendapatkan perlindungan hukum dari pasal tersebut, dikarenakan pasal tersebut memiliki kekuatan eksekutorial yang sama dengan keputusan pengadilan, dengan syarat debitor/ pemberi hak tanggungan cidera janji. Dengan demikian, hak untuk menjual objek hak tanggungan atas kekuasaan sendiri adalah perwujudan kedudukan yang diutamakan yang dipunyai pemegang hak tanggungan atau pemegang hak tanggungan peringkat pertama dalam hal terdapat lebih dari satu pemegang hak tanggungan. Hak tersebut didasarkan pada janji yang diberikan oleh pemberi hak tanggungan bahwa apabila debitor cidera janji, pemegang hak tanggungan berhak untuk menjual objek hak tanggungan melalui pelelangan umum misalanya saja dengan prosedur secara online, tanpa memerlukan persetujuan lagi dari pemberi hak tanggungan dan selanjutnya mengambil pelunasan piutangnya dari hasil penjualan tersebut dan didahulukan dibandingkan kreditor-kreditor lain. Sisa hasil penjualan tetap menjadi hak pemberi hak tanggungan, namun apabila dari hasil penjualan objek hak tanggungan melalui pelelangan tidak menutupi kewajiban debitor, maka debitor masih memiliki kewajiban kepada kreditor.

Kedua, selalu mengikuti objek yang dijaminkan. Maksudnya adalah dalam tangan siapapun objek itu berada, apabila di dalam sertifikat hak 
tanggungan dan APHT tertulis pemegang objek hak tanggungan adalah pihak kreditor, maka siapapun yang menempati objek tersebut atau merasa menguasai objek tersebut tidak memiliki hak, sampai lunasnya kewajiban dari debitor/ pemberi hak tanggungan. Ketiga, memenuhi asas spesialitas dan publisitas. Hal ini menjelaskan bahwa hak tanggungan dapat mengikat pihak ketiga dan memberikan kepastian hukum kepada pihak-pihak yang berkepentingan.

Keempat, mudah dan pasti pelaksanaan eksekusinya. Pelaksanaan eksekusi objek hak tanggungan hanya berdasar kepada wanprestasinya seorang debitor kepada kreditor sesuai dengan perjanjian kredit yang telah disepakati kedua belah pihak. Selama telah diberikan peringatan 1, 2, dan 3 dari pihak kreditor, meskipun tunggakan dari pihak debitor sangatlah kecil, pihak kreditor mendapat perlindungan dari UUHT untuk mendaftarkan permohonan pelelangan objek hak tanggungan ke KPKNL. Apabila telah ditetapkannya jadwal pelaksanaan lelang dari KPKNL, maka pelelangan tersebut hanya dapat dibatalkan oleh pihak debitor/ pemberi hak tanggungan dengan menunjukkan bukti pelunasan kewajiban secara keseluruhan kepada KPKNL 5 hari sebelum pelaksanaan lelang dilakukan.

\section{b. Perlindungan Hukum Terhadap Pelelangan Objek Hak Tanggungan Secara Online Bagi Debitor}

Pasal 20 ayat (2) UUHT, menyatakan bahwa "atas kesepakatan pemberi dan pemegang Hak Tanggungan, penjualan objek Hak Tanggungan dapat dilaksanakan di bawah tangan jika dengan demikian itu akan diperoleh harga tertinggi yang menguntungkan semua pihak". Terlihat bahwa wujud perlindungan kepentingan para pihak, sekalipun yang paling berkepentingan tentunya adalah pemberi hak tanggungan. Apabila penilaian jaminan, yang dulu dilakukan kreditor, diperkirakan sangat tipis dengan taksiran harga jual sekarang, dan taksiran harga jual dekat atau lebih kecil dengan kredit kreditor, maka kreditor pemegang hak tanggungan berkepentingan sekali atas penjualan jaminan dengan harga yang tinggi, dengan pengharapan seluruh tagihannya akan tertutup. Sudah tentu pemberi hak tanggungan juga mengharapkan harga yang tinggi, sebab sisa penjualan sesudah diambil kreditor adalah haknya. Apabila dalam proses pelaksanaan pelelangan dari proses pemberian surat peringatan sampai penetapan pemenang lelang pihak debitor merasa dirugikan karena tidak sesuai prosedur, yang bersangkutan berhak melakukan upaya hukum yaitu melakukan gugatan secara perdata ke Pengadilan Negeri. 


\section{c. Perlindungan Hukum terhadap Pelelangan Objek Hak Tanggungan Secara Online bagi Pemenang Lelang}

Hak tanggungan merupakan perlindungan hukum bagi kreditor apabila debitor tidak dapat melakukan kewajibannya untuk melunasi hutangnya kepada kreditor. Pelunasan hutang kreditor dilakukan dengan cara penjualan objek jaminan hak tanggungan melalui pelelangan umum. Permasalahan dalam pelelangan terjadi ketika pemenang lelang tidak dapat menguasai objek lelang yang dibelinya dikarenakan susahnya pengosongan dan adanya gugatan dari pihak debitor ataupun pihak ketiga. Perlindungan hukum harus diberikan terhadap pemenang lelang yang berarti adanya kepastian hukum hak pemenang lelang atas objek yang dibelinya melalui lelang. Proses lelang yang telah dilakukan akan menimbulkan akibat hukum yaitu peralihan hak objek lelang dari penjual kepada pemenang lelang.

Terhadap permasalahan pertama untuk sulitnya melakukan pengosongan, pemenang lelang pada dasarnya sudah sepenuhnya memiliki hak terhadap objek tersebut. Pemenang lelang dapat membuat permohonan kepada pengadilan untuk mengeksekusi atau mengosongkan jaminan tersebut dari debitor atau pihak ketiga dengan menunjukkan risalah lelang yang dalam hal ini memiliki kekuatan sama dengan putusan pengadilan. Hal tersebut dikarenakan risalah lelang merupakan berita acara pelaksanaan lelang yang dibuat oleh Pejabat Lelang yang merupakan akta otentik dan mempunyai kekuatan pembuktian sempurna. Selain sebagai dasar permohonan eksekusi ke pengadilan, risalah lelang juga dapat digunakan sebagai dasar balik nama ke BPN tanpa harus meminta persetujuan terlebih dahulu kepada debitor ataupun pemilik sertifikat objek hak tanggungan sebelumnya, karena risalah lelang sama halnya dengan akta jual beli.

Apabila terjadi permasalahan kedua, yaitu tidak sah atau batalnya lelang dikarenakan putusan pengadilan yang timbul karena adanya gugatan dari debitor atau pihak ketiga, meskipun pada praktiknya hal semacam ini jarang terjadi, namun akan ada akibat hukum terhadap pembeli atau pemenang lelang. Akibat hukum terhadap pembeli lelang dapat dilihat dari segi barang objek lelang dan dari segi hasil lelang yang telah disetorkannya seharga yang telah diputuskan, baik pembayaran harga nilai jaminan, BPHTB, dan bea lelang. Jika putusan menyatakan lelang batal dan tidak sah, maka hak pembeli lelang atas objek lelang akan menjadi berakhir. Hal ini berlaku sejak jual beli lelang baru pada tahap setelah penunjukan pembeli lelang sebagai pemenang, maupun setelah barang objek lelang telah dilakukan, penyerahan baik penyerahan nyata atau fisik melalui pengosongan maupun penyerahan yuridis melalui balik nama di kantor pertanahan. Sedangkan dari hasil lelangnya maka akan dikembalikan oleh pihak yang menjadi kuasa undang-undang mewakili pemilik barang sebagai 
penjual, diantaranya bank kreditor atau termohon eksekusi atau pemegang hak tanggungan.

\section{d. Perlindungan Hukum terhadap Pelelangan Objek Hak Tanggungan Secara Online bagi KPKNL/ Pejabat Lelang dan Kaitannya dengan BPN}

Pejabat lelang adalah orang yang berdasarkan peraturan perundangundangan diberi wewenang khusus untuk melaksanakan penjualan barang secara lelang. KPKNL sebagai pihak penyelenggara pelelangan objek hak tanggungan secara online yang dalam hal ini diwakili oleh pejabat lelang di dalam pelaksanaan pelelangan memang pada dasarnya akan dilindungi oleh undang-undang selama prosedur yang dijalankan menurut ketentuan yang berlaku. Misalnya saja di dalam risalah lelang, akan ada lembar yang menyatakan bahwa sebelum pelelangan objek Hak Tanggungan secara online melalui ALE dimulai pada alamat http://www.lelangdjkn.kemen keu.go.id akan ada hal yang ditekankan yang salah satunya menyatakan bahwa Pejabat Lelang/KPKNL tidak menanggung atas kebenaran keterangan-keterangan tentang keadaan sesungguhnya dan keadaan hukum atas barang yang dilelang tersebut, seperti luasnya, batas-batasnya, perjanjian sewa menyewa dan semuanya menjadi resiko pembeli. Serta Penawar/Pembeli telah dianggap sunguh-sungguh telah mengetahui apa yang telah ditawar olehnya. Apabila terdapat kekurangan/kerusakan baik yang terlihat ataupun yang tidak terlihat, maka Penawar/Pembeli tidak berhak untuk menolah atau menarik diri kembali setelah pembelian disahkan dan melepaskan segala hak untuk meminta kerugian atas sesuatu apapun juga. Hal tersebut di atas seakan-akan membuat terlihat bahwa KPKNL tidak menjamin terkait jaminan berupa tanah bersih dan jelas. Perlu digaris bawahi KPKNL sebagai penyelenggara lelang hak tanggungan secara online tidak bisa melaksanakan pelelangan tanpa adanya Surat Keterangan Pendaftaran Tanah (SKPT), dan SKPT hanya dapat diterbitkan oleh BPN. Terkait hal ini, BPN selaku penerbit SKPT hanya dapat menguji keterangan secara formil namun tidak bisa secara materiil. Hal tersebutlah yang menjadi dasar KPKNL tidak bertanggung jawab terkait objek hak tanggungan, dikarenakan telah ada lembaga lain yang menguji dengan bukti SKPT.

Terhadap hal-hal tersebut di atas akan ditandatangani oleh pihak yang terkait dengan pelelangan objek hak tanggungan secara online di dalam risalah lelang. Risalah lelang tersebutlah yang menjadi dasar balik nama ke BPN tanpa harus adanya Akta Jual Beli. Bahkan BPN harus menerbitkan sertifikat meski baru. Meskipun hal tersebut menguatkan perlindungan hukum bagi pihak penyelenggara pelelangan yang dalam hal ini KPKNL/Pejabat Lelang, namun seharusnya Pejabat Lelang haruslah bersifat aktif, misalnya saja dalam penentuan nilai limit yang ditetapkan oleh 
Penjual, pihak KPKNL secara langsung mengecek ke lokasi jaminan untuk melihat apakah ada kesalahan dari penilaian harga jaminan tersebut. Kemudian terhadap jaminan, seharusnya pihak KPKNL sebagai pihak yang independen bisa menginformasikan kepada calon pembeli atau peserta lelang mengenai status jaminan tersebut, kondisi jaminan dan hal yang dibutuhkan oleh calon pembeli, karena apabila yang menginformasikan adalah penjual, sudah dapat dipastikan hanya hal yang baik saja yang akan diberitahukan.

\section{Penutup}

\section{Simpulan}

Kepastian hukum untuk pemenang lelang ada pada risalah lelang yang dikeluarkan secara tertulis oleh Pejabat Lelang. Risalah Lelang merupakan akte otentik yang digunakan penjual/pemilik barang, pembeli dan Pejabat Lelang untuk mempertahankan dan melaksanakan hak dan kewajibannya serta mempunyai kekuatan pembuktian sempurna sesuai dengan Pasal 1 Angka 32 Peraturan Menteri Keuangan Nomor 106/PMK.06/2013 baik terhadap hasil lelang konvensional maupun online.

Peraturan pelaksana lelang saat ini telah memberikan perlindungan hukum terhadap pihak-pihak yang terkait di dalamnya. Pihak kreditor mendapatkan perlindungan hukum dari UUHT. Pihak debitor mendapatkan perlindungan hukum melalui jalur pengadilan apabila merasa ada kesalahan prosedur dalam pelelangan objek hak tanggungan tersebut. Pihak pemenang lelang mendapatkan perlindungan hukum dari risalah lelang yang merupakan akta otentik dan memiliki kekuatan pembuktian sempurna. KPKNL sebagai penyelenggara pelelangan melalui Pejabat Lelang mendapat perlindungan hukum selama mengikuti petunjuk teknis pelaksanaan lelang dan prosedur sesuai dengan ketentuan yang berlaku.

\section{Saran}

a. Optimalisasi pelelangan Hak Tanggungan yang efektif, yaitu dengan meyakinkan kepada masyarakat bahwa penjualan barang melalui lelang secara online sah menurut hukum dan menjamin kepemilikan terhadap benda tersebut, sehingga peminat ataupun peserta lelang di KPKNL semakin banyak.

b. BPN selaku penerbit SKPT memang menjamin secara yuridis obejk Hak Tanggungan, namun pihak KPKNL/Pejabat Lelang seyogyanya lebih bersifat aktif untuk turun secara langsung ke lapangan, hal tersebut untuk memitigasi kesalahan nilai limit lelang, maupun kondisi jaminan, sehingga akan lebih memberikan perlindungan hukum dan meminimalisir resiko hukum bagi pihak-pihak yang terkait dengan pelelangan. 


\section{Daftar Pustaka}

\section{A. Buku}

Al-Rashid, Harun. (1997). Sekilas Jual Beli Tanah. Jakarta: Ghalia Indonesia.

Budiman, Arif. (1984). Sosiologi Pembangunan dan Keterbelakangan Sosiologi. Jakarta: Pustaka Pulsar.

Departemen Keuangan Republik Indonesia. (1995). Lelang Barang-Barang Milik Badan Usaha Milik Negara/Daerah. Bandung: Badan Urusan Piutang dan Lelang Negara, Kantor Wilayah IV Kantor Lelang Negara.

Harsono, Boedi. (1999). Hukum Agraria Indonesia, Sejarah Pembentukan Undang-Undang Pokok Agraria, isi dan pelaksanaannya. Jakarta: Djambaran.

Sutedi, Adrian. (2010). Hukum Hak Tanggungan. Jakarta: Sinar Grafika.

\section{B. Karya Ilmiah}

Sutarjo. (1995). "Pelelangan Dalam Rangka Eksekusi Oleh Pengadilan Negeri dan PUPN, Serta Aspek-Aspek Hukum yang Timbul Dalam Praktek". Makalah Penyuluhan Lelang. Medan.

\section{Peraturan Perundang-Undangan}

Kitab Undang-Undang Hukum Perdata.

Undang-Undang Nomor 4 Tahun 1996 tentang Hak Tanggungan Atas Tanah

Serta Benda-Benda Yang Berkaitan Dengan Tanah.

Undang-Undang Nomor 5 Tahun 1960 tentang Peraturan Dasar PokokPokok Agraria.

Undang-Undang Nomor 11 Tahun 2008 tentang Informasi dan Transaksi Elektronik.

Peraturan Pemerintah Nomor 24 Tahun 1997 tentang Pendaftaran Tanah.

Peraturan Menteri Keuangan Republik Indonesia Nomor 93/PMK.06/2010 sebagaimana telah diubah Peraturan Menteri Keuangan Republik Indonesia Nomor 106/PMK.06/2013 tentang Petunjuk Pelaksanaan Lelang.

Peraturan Direktur Jenderal Kekayaan Negara Nomor 6/KN/2013 tentang Petunjuk Teknis Pelaksanaan Lelang. 